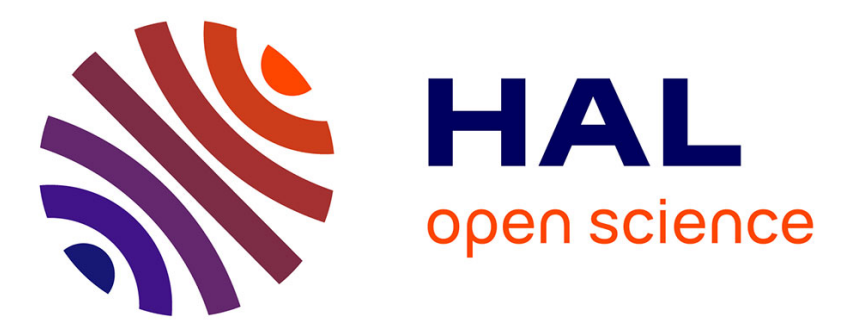

\title{
Computational Linguistics and Its Implementation in e-Learning Platforms
}

Marcel Pikhart

\section{To cite this version:}

Marcel Pikhart. Computational Linguistics and Its Implementation in e-Learning Platforms. 18th Conference on e-Business, e-Services and e-Society (I3E), Sep 2019, Trondheim, Norway. pp.634-640, 10.1007/978-3-030-29374-1_51. hal-02510090

\section{HAL Id: hal-02510090 \\ https://hal.inria.fr/hal-02510090}

Submitted on 17 Mar 2020

HAL is a multi-disciplinary open access archive for the deposit and dissemination of scientific research documents, whether they are published or not. The documents may come from teaching and research institutions in France or abroad, or from public or private research centers.
L'archive ouverte pluridisciplinaire HAL, est destinée au dépôt et à la diffusion de documents scientifiques de niveau recherche, publiés ou non, émanant des établissements d'enseignement et de recherche français ou étrangers, des laboratoires publics ou privés. 


\title{
Computational linguistics and its implementation in e- Learning platforms
}

\author{
Marcel Pikhart \\ Faculty of Informatics and Management, University of Hradec Kralove, Rokitanskeho, Hradec \\ Kralove, 50003, Czech Republic \\ marcel.pikhart@uhk.cz
}

\begin{abstract}
We have experienced in the past few years massive use of various kinds of e-Learning methodology, such as m-learning and blended learning etc. Despite this ubiquitous implementation of these modern approaches, we still lack their proper use regarding their full exploitation in the virtual learning environment. M-learning platforms are ubiquitous, however, they lack the potential which is given to us from computational linguistics, deep learning, and artificial intelligence. The paper attempts to highlight this fact and brings this neglected topic to the attention of the creators and designers of these mobile apps because their potential is much greater and we should put our undivided attention to this issue if we want to improve the technology which we use.
\end{abstract}

Keywords: Artificial intelligence, computational linguistics, e-Learning, mLearning, blended learning, corpus linguistics, natural language processing, deep learning

\section{$1 \quad$ Literature review}

In the past few years, we have experienced a vast increase in the use of mobile devices used for various purposes such as communication, learning, teaching, data processing, planning, etc. $[4,10,14,15,17,24,26,30,35,40]$. Mobile devices are present and used every day and everywhere, regardless the society and culture globally $[2,5,31$, $39,40,43]$. Traditional desktops have seen a decline recently and, on the contrary, mobile apps and tools have experienced a dramatic rise [16, 19, 28,39]. The number of the users is increasing year on year in a dramatic pace, and all these aspects of modern society must be reflected by the professionals responsible for the development of the area of smart learning, e-Learning, hybrid learning, etc. [8, 18]

In education, this rise described above is very similar and follows the same trend $[12,13,44,45,46]$, i.e. more and more people are using computers and smart devices on a daily basis [7], not only for basic communication with the tutor but as - potentially - a very efficient tool for educational purposes [11, 20, 21, 25, 27, 29].

It is mostly the young generation which cannot imagine its life without these tools of everyday life. Educational professionals and IT professional have a unique chance 
to use this opportunity and implement these modern tools into educational process on a larger scale.

Despite all the facts, the topic of the use of artificial intelligence and computational linguistics in e-Learning is basically non-existent, not only in theory in academic papers but also in practice of the use of mobile apps. The opportunities of the use and implementation of computational linguistics and artificial intelligence are vast and it is a question why this topic still lacks attention of the creators of various online learning courses, i.e. e-Learning tools and platforms.

Naturally, there are many apps which have implemented the computational linguistics practice, deep learning and artificial intelligence, however, the trend in e-learning and $\mathrm{m}$-Learning is still rather old fashioned, i.e. these platforms are still used more like repository warehouses for data and texts to be studied and don't use their full potential, i.e. information analysis through modern means of artificial intelligence. The possibilities are vast, however, still neglected, and this paper brings this topic into attention of the creators and professionals who are active in IT business and therefore responsible for the implementation of the modern tools into various technological aspect of human communication, interaction and learning [7, 23, 25, 27].

The efficiency of the use of e-Learning, m-Learning, blended learning, etc., has already been proven significantly $[32,33,34]$ and it must be taken into consideration so that it is added to traditional approaches in educational processes [41, 42] and mostly in language acquisition of grammar and vocabulary [3, 22, 36, 37, 38].

The use of e-Learning tools is so ubiquitous in our universities and other educational institutions that it is complicated to acknowledge the fact that a systematic approach to creation of the courses is still missing and the implementation of artificial intelligence into these courses is still more or less non-existent.

\section{Computational linguistics in e-Learning}

Computational linguistics has been used for decades, not only by linguistics but also by IT specialists, however, the massive use of this extremely useful tool is still expected and this paper is an attempt to urge this process. The use of artificial intelligence and computational linguistics in mobile platforms has been proven to be extremely useful in the learning process $[1,6,9]$ as the student receives updated motivation based on their progress in the learning process.

Computational linguistics uses very efficient tools of data analysis which can be very beneficial when creating larger texts, assessing of the progress of students, creating more systematic approach to the learning process by analysing big data and using data mining so that the input is more optimised and the output more targeted to the current needs of the users of the app or mobile platform [23].

The most important use of these modern tools is in data processing based on the development of the situation, i.e. the progress of the information is important for further information processing. For example, if the students use a mobile platform, they are provided with the information based on their previous information processing - if the 
student is tested and makes mistakes, they will be provided with the information which still contains the yet not acquired information until it is acquired properly. This beneficial tool supported by computational linguistics is simple, however, brings incredible progress if implemented in the learning platforms which are already in use.

When using computational linguistics and even artificial intelligence, we are equipped with the tools we never had available and these tools bring many opportunities to data processing and management that must be used and exploited as much as possible.

\section{Research}

The research was conducted by the author of the paper into the use of any kind of artificial intelligence in e-learning platforms which are currently used in our universities, such as the Blackboard and Moodle. These environments are extremely popular both in the creators of curricula and the users, i.e. university students because they provide us with comfortable tools which can be used easily without the need to attend the classes physically.

The author of the research has access to both platforms (Blackboard and Moodle) because he is a teacher at two Czech universities which use both of them. The subjects varied but were mostly language classes (English and German), finance, and economics.

The research was qualitative and was conducted in January 2019. Data were collected by analysis and comparison of the online courses of the given universities. The author visited online courses as a fictitious student, the data were collected, and researched the contents and structure of the classes. The total number of the university courses which were researched was 46, equally spread through Blackboard and Moodle, from both universities which both have more than 15,000 students and are considered to be the major educational institutions in the Czech Republic.

\section{The result of the research and discussion}

The research results are extremely surprising. Forty-six online university courses were researched, however, none of them uses any kind of artificial intelligence, deep learning or computational linguistics methodology. The most surprising is that even language courses did not use any of these tools.

The e-Learning platforms were used only as text repositories without any interactive environment which could be fostered by the use of computational linguistics and other kinds of artificial intelligence. Even the tests were just online tests without any interaction with the student based on their previous progress during their studies. Both platforms were used but not appropriately and it is also due to the lack of these basic tools in themselves. Neither Blackboard nor Moodle, even if they are used massively in our universities, do not provide efficient computational linguistics tools which would process the information and create an adapted course based on the needs of the users. 
It is difficult to accept that in the year 2019 when artificial intelligence progress and computational linguistics findings are vast and unprecedented, we still lack any sign of this progress implemented in e-Learning, even if we know that the implementation of these basic technological tools for data processing would change the learning process positively and the progress would be enormous.

It is crucial to redesign all e-Learning courses with the use of artificial intelligence as it will move the traditional learning process a few levels higher compared to the current situation and it will also provide us with a dramatic improvement in our competiveness. Big data and machine learning will also provide us with indispensable tools for data analysis which will help us to create more targeted and personally oriented webs, apps, tests, learning contents, etc. These are crucial improvements in the educational paradigm and IT professionals with the cooperation with educators are now fully responsible for this challenge.

\section{Conclusion}

The author of the paper claims that the use of electronic platforms with the implementation of computational linguistics and deep learning is not at all sufficient and is rather a misunderstanding of modern technological tools which equip us with so many opportunities. They are merely used as a classic pen and paper tests and simple electronic communication tools. If we do not move forward, both designers and creators of these course in favour of artificial intelligence and computational linguistics, we can never succeed and it will present a potential threat to our global competitiveness and sustainability.

The paper attempts to show the absolute lack of the use of artificial intelligence and computational linguistics in our universities e-Learning platforms and claims that it is one of the biggest problems in the further development of educational processes. It also ought to stimulate professionals who are in IT industry such as the creators of various apps and platforms to enhance the need to implement artificial intelligence into these tools.

\section{Acknowledgements}

The paper was created with the support of SPEV 2019 at the Faculty of Informatics and Management of the University of Hradec Kralove, Czech Republic. The author would like to thank the student Jan Sprinar for his help when collecting the data of the research.

\section{References}

1. Alpaydin, E. (2016) Machine Learning. The New AI. MIT Press 
2. Alghabban, W.G., Salama, R.M., \& Altalhi, A.H. (2017). Mobile cloud computing: An effective multimodal interface tool for students with dyslexia. Computers in Human Behavior, 75, 160-166.

3. Balula, A., Marques, F., \& Martins, C. (2015). Bet on top hat - challenges to improve language proficiency. Proceedings of EDULEARN15 Conference 6-8 July 2015 (pp. 26272633). Spain: Barcelona.

4. Berger A., \& Klímová B. (2019). Mobile application for the teaching of English. In: Park J., Loia V., Choo KK., Yi G. (eds) Advanced Multimedia and Ubiquitous Engineering. MUE 2018, FutureTech 2018. LNEE, 518, 1-6.

5. Bidaki, M.Z., Naderi, F., \& Ayati, M. (2013). Effects of mobile learning on paramedical students' academic achievement and self-regulation. Future of Medical Education Journal, $3(3), 24-28$.

6. Buckland, M. (2017) Information and Society. MIT Press

7. Cheung, S. K. S. (2014). A case study on the students' attitude and acceptance of mobile learning CCIS 2014 (pp. 45-54). Heidelberg: Springer.

8. Chinnery, G. (2006). Going to the MALL: mobile assisted language learning. Language Learning and Technology, 10(1), 9-16.

9. Clark, A. et all (2010) The Handbook of Computational Linguistics and Natural Language Processing. Chichester: Blackwell

10. Dupalova, P. (2014). Hodnocení aplikací na mobilní zařízení zaměřující se na samostatné studium slovní zásoby $\mathrm{V}$ anglickém jazyce. Retrieved 16 February 2019, from https://otik.uk.zcu.cz/bitstream/11025/24285/1/Graduate\%20Thesis_Petra\%20Dupalova.pdf .

11. Elfeky, A.I.M., \& Masadeh, T.S.Y. (2016). The effect of mobile learning on students' achievement and conversational skills. International Journal of Higher Education, 5(3), 2031 .

12. Gideon, A. (2017). Influence of time-on-phone on undergraduates academic achievement in Nigerian universities. American Journal of Educational Research, 5(5), 564-567.

13. Klimova, B. (2016). Teacher's Role in a Smart Learning Environment-A Review Study. In V. Uskov, R.J., Howlett, and L.C. Jai (Eds.) Smart Innovation, Systems and Technologies, vol. 59, pp. 51-59. Springer.

14. Klimova, B. (2017). Assessment in the eLearning course on academic writing - A case study. In: Wu TT., Gennari R., Huang YM., Xie H., Cao Y. (eds) Emerging Technologies for Education. SETE 2016. LNCS, vol. 10108, 733-738.

15. Klímová, B., \& Berger, A. (2018). Evaluation of the use of mobile application in learning English vocabulary and phrases - A case study. In: Hao T., Chen W., Xie H., Nadee W., Lau R. (eds) Emerging Technologies for Education. SETE 2018. LNCS, 11284, 3-11.

16. Klimova, B., \& Poulova, P. (2015). Mobile learning and its potential for engineering education. Proceedings of 2015 I.E. Global Engineering Education Conference (EDUCON 2015) (pp. 47-51). Estonia, Tallinn: Tallinn University of Technology.

17. Klimova, B., \& Poulova, P. (2016). Mobile learning in higher education. Advanced Science Letters, 22(5/6), 1111-1114.

18. Klimova B., Simonova I., Poulova P. (2017). Blended learning in the university English courses: Case study. In: Cheung S., Kwok L., Ma W., Lee LK., Yang H. (eds) Blended Learning. New Challenges and Innovative Practices. ICBL 2017. Lecture Notes in Computer Science, vol 10309. Springer, pp. 53-64. 
19. Kukulska-Hulme, A., \& Shield, L. (2008). An overview of mobile assisted language learning: From content delivery to supported collaboration and interaction. ReCALL, 20(3), 271-289.

20. Lameris, A.L., Hoenderop, J.G.J., Bindels, R.J.M., \& Eijsvogels, T.M.H. (2015). The impact of formative testing on study behaviour and study performance of (bio)medical students: a smartphone application intervention study. BMC Medical Education, 15, 72.

21. Lee, P. (2014). Are mobile device more useful than conventional means as tools for learning vocabulary? Proceedings of the 8th International Symposium on Embedded Multicore/Mangcore SoCs (pp. 109-115). IEEE.

22. Lewis, B. (1993). The lexical approach. London: LTP.

23. Lopuch, M. (2013). The effects of educational apps on student achievement and engagement. Retrieved 2 March 2018, from http://www.doe.virginia.gov/support/technology/technology_initiatives/e-learning_backpack/institute/2013/Educational_Apps_White_Paper_eSpark_v2.pdf.

24. Luo, B.R., Lin, Y.L., Chen, N.S., Fang, W.C. (2015). Using smartphone to facilitate English communication and willingness to communicate in a communicative language teaching classroom. Proceedings of the 15th International conference on Advanced Learning Technologies (pp. 320-322). IEEE.

25. Males, S., Bate, F., \& Macnish, J. (2017). The impact of mobile learning on student performance as gauged by standardised test (NAPLAN) scores. Issues in Educational Research, 27(1), 99-114.

26. Mehdipour, Y., \& Zerehkafi, H. (2013). Mobile learning for education: Benefits and challenges. International Journal of Computational Engineering Research, 3(6), 93-101.

27. Miller, H.B., \& Cuevas, J.A. (2017). Mobile learning and its effects on academic achievement and student motivation in middle grades students. International Journal for the Scholarship of Technology Enhanced Learning, 1(2), 91-110.

28. Moher, D., Liberati, A., Tetzlaff, J., \& Altman, D. G. (2009). The PRISMA group. Preferred reporting items for systematic review and meta-analysis: the PRISMA statement. PLoS Medicine, 6, e1000097.

29. Muhammed, A. A. (2014). The impact of mobiles on language learning on the part of English foreign language (EFL) university students. Procedia - Social and Behavioral Sciences, 136, 104-108.

30. Oz, H. (2013). Prospective English teachers' ownership and usage of mobile device as mlearning tools. Procedia-Social and Behavioral Sciences, 141, 1031-1041

31. Pew Research Center. (2018). Mobile fact sheet. Retrieved 16 February 2019, from http://www.pewinternet.org/fact-sheet/mobile/.

32. Pikhart, M. (2018) Sustainable communication strategies for business communication. Proceedings of the 32nd International Business Information Management Association Conference (IBIMA). p. 528-53. 15-16 November 2018 Seville, Spain. Ed. Khalid S. Soliman. International Business Information Management Association. ISBN: 978-0-9998551-1-9

33. Pikhart, M. (2018a) Intercultural Business Communication Courses in European Universities as A Way to Enhance Competitiveness, Proceedings of the 32nd International Business Information Management Association Conference (IBIMA). p. 524-527. 15-16 November 2018 Seville, Spain. Ed. Khalid S. Soliman. International Business Information Management Association. ISBN: 978-0-9998551-1-9

34. Pikhart, M. (2018b) Multilingual and intercultural competence for ICT: Accessing and assessing electronic information in the global world (MISSI 2018). Advances in Intelligent 
Systems and Computing, Volume 833, 2019, Pages 273-278. 11th International Conference on Multimedia and Network Information Systems, MISSI 2018; Wroclaw; Poland; 12 September 2018 through 14 September 2018. ISSN 2194-5357. DOI 10.1007/978-3-319-98678428

35. Pikhart, M. (2018c) Technology Enhanced Learning Experience in Intercultural Business Communication Course: A Case Study. In Emerging Technologies for Education. Third International Symposium, SETE 2018, Held in Conjunction with ICWL 2018, Chiang Mai, Thailand, August 22-24, 2018, Revised Selected Papers. Book Series: Lecture Notes in Computer Science, Editors: Tianyong Hao, Wei Chen, Ha, Publisher: Springer International Publishing,Print ISBN: 978-3-030-03579-2, Electronic ISBN: 978-3-030-03580-8.

36. Sandhya, K., Smitha, J., \& Asha, J.V. (2017). Mobile learning apps in instruction and students achievement. IJIM, 11(1), 143-147.

37. Schmitt, N., \& McCarthy, M. (2008). Vocabulary: description, acquisition and pedagogy. Cambridge: CUP.

38. Shih, R. C., Lee, C., \& Cheng, T. F. (2015). Effects of English spelling learning experience through a mobile LINE APP for college students. Procedia - Social and Behavioral Sciences, 174, 2634-2638.

39. Statcounter. Mobile Operating System Market Share Worldwide. Retrieved 16 February 2019 from, http://gs.statcounter.com/os-market-share/mobile/worldwide/\#monthly200901-201812.

40. Sung, Y.T., Chang, K.E., \& Liu, T.C. (2016). The effects of integrating mobile devices with teaching and learning on students' learning performance: A meta-analysis and research synthesis. Computers \& Education, 94, 252-275.

41. Tayan, B. M. (2017). Students and teachers' perceptions into the viability of mobile technology implementation to support language learning for first year business students in a Middle Eastern university. International Journal of Education \& Literacy Studies, 5(2), 74 83.

42. Teodorescu, A. (2015). Mobile learning and its impact on business English learning. Procedia - Social and Behavioral Sciences, 180, 1535-1540. Tingir S., Cavlazoglu, B., Caliskan, O., Koklu, O., \& Intepe-Tingir, S. (2017). Effects of mobile devices on $\mathrm{K}-12$ students' achievement: a meta-analysis. Journal of Computer Assisted Learning, 33(4), 355-369.

43. West, M., \& Vosloo, S. E. (2013). UNESCO policy guidelines for mobile learning. Paris: UNESCO.

44. Wu, Q. (2014). Learning ESL vocabulary with smartphones. Procedia - Social and Behavioral Sciences, 143, 302-307.

45. Wu, Q. (2015a). Designing a smartphone app to teach English (L2) vocabulary. Computers \& Education. https://doi.org/10.1016/j.compedu.2015.02.013.

46. Wu, Q. (2015b). Pulling mobile assisted language learning (MALL) into the mainstream: MALL in broad practice. PLoS One, 10(5), e0128762. 